\title{
Features of the Modern System of Management of Development of Enterprises
}

\author{
Karine Alexandrovna Barmuta \\ Anna Anatolievna Borisova \\ Mariya Pavlovna Glyzina \\ Don State Technical University (DSTU), Rostov-on-Don, Russia \\ Email: carinaba@yandex.ru
}

Doi:10.5901/mjss.2015.v6n3s4p91

\section{Abstract}

Entering the era of the "knowledge economy", where the main sources of well-being and leading factors of production are innovation and creativity (intellectual) the achievements of people led to survival in modern conditions only those businesses that are flexible in responding to market demands, create and organize the production of competitive products provide an efficient restructuring of internal control, that is developing. In modern conditions, innovation has become a major factor in improving the efficiency of industrial enterprises, making it impossible to use the old management approaches. Industrial enterprise can be considered innovative and promising to develop, if the trends of this development are due to the comprehensive implementation of all types of innovation: product and process. The increase of complexity management in its development should precede the development of production, only then it can be effective. Improving the system of management of the effective development of industrial enterprises is one of the main problems of Russian economic development. Central to the effective management of industrial enterprises becomes the adequacy of the used instrumentation control conditions in the socio-economic system in which social production functions. This will provide an improved process for the management of the enterprise to achieve its effective development. On the basis of generalization of the results of theoretical research and practice the basic problems of management of modern industrial enterprises, highlighted the assumptions of the new market-based management concept, identified the characteristics of the new managerial paradigm inherent to Russian enterprises and adequate to the new economy.

Keywords: management development, innovation, management paradigm.

\section{Introduction}

The specificity of the market economy, the variability of external and internal environment to determine every company need not only to make decisions independently, but also be fully accountable for their results. In the process of implementing the activities of the industrial enterprise, it is advisable to consider the factors of effective development to ensure that there was the ability to adequately and timely respond to changes in the external or internal environment. To industrial enterprise has reached the effective development, it is necessary to improve the process of business management (Aspridis, Kazantzi \& Kyriakou, 2013).

Undoubtedly, the development must be managed, i.e. to a greater extent be adjusted towards managerial impact. The institutional concept of control as the term denoting the means of achieving the object of the desired results, it is applicable to the process of enterprise development. The essence of development management is to achieve the planned level of development results at a particular time. Market fluctuations and the closely related activities of the economic entity can lead to slower development, as well as to the processes of stagnation or even destruction of the organization. Influence of management is intended to mitigate the possible negative impact of such fluctuations.

\section{Management Problems of Modern Industrial Enterprises}

Content analysis of existing theories of organization development leads to the conclusion that they are complementary, as focus on specific aspects of: neoclassical - on production process, institutional - formal and informal interactions between people and organizations, evolutionary - on the reasons for the changes, entrepreneurial - on innovation. Thus, the management of enterprise development should be based on integrated approaches.

The main distinguishing feature of Russian companies is that they operate in a constantly changing economic 
environment. In fact, management is faced with the problem of control under conditions of uncertainty (Dimitrios, 2012).

The company has a number of features inherent in economic production systems:

- Biggest challenge, due to the presence of multiple and strong material and information links between elements;

- A continuous, dynamic and non-recurring development;

- Continuous influence of natural factors and society, and these effects are in large part are largely stochastic in nature, which determines the need to operate and make decisions in conditions of uncertainty.

Therefore, the enterprise management system must meet current market conditions, namely:

- possess a high flexibility from the standpoint of production, ensures a timely response to market demands products. This is because the product life cycle becomes shorter, and the variety of products.

To be adequate complex production technologies those require an entirely new form of control, organization and division of labor;

- Consider serious competition on the market of goods (services), radically changed the attitude towards the quality of products requiring organize after-sales service and additional corporate services;

- Take into account the requirements to the level of quality of customer service and run-time contracts, which have become too high for traditional production systems and mechanisms for management decision making;

- To take into account changes in the structure of production costs;

- Take into account the necessity of accounting for the uncertainty of the external environment.

This is not a complete list of problems faced by enterprises. For their solution there is an objective need for research, the analysis of the existing situation.

In the current environment to effectively manage the company primarily means to determine the direction of the company, to develop its strategy and objectives, to plan the types and amounts of products, organize sales activities to meet consumer demand, and, in addition, with maximum efficiency to adapt the organizational structure of the enterprise to changing conditions of its functioning to achieve these goals (Altukhov \& Mitsuk, 2006).

Decisions within these areas should be based on the principle of economic efficiency, that is, the basis should be based on the desire to obtain the greatest economic results with the lowest possible cost of all necessary resources.

With the increasing role of innovation in the development of enterprises at the present time, it becomes impossible to use the old management approaches. The reason is that the company can be innovative and promising to develop, if the trends of this development is due to the comprehensive implementation of all types of innovation: product and process. In favor of these arguments in the work of N. Afanasyeva In. notes: "...the development of production should occur in parallel with the development of forms and methods of management. At the beginning of economic growth can be monoprice and relatively simple methods of management. The increase of complexity management in its development should precede the development of production and only then it can be effective. All this entails a complication in functional, organizational, motivational, informational relations and further complete reorganization of the management and the managed subsystems" (Afanasev \& Rogozhin, 2003).

With the development of market relations in Russia is becoming more evident that it is impossible to achieve sustained business success, while remaining under the previous system of enterprise management. Features of the transition economy, the particular mentality and cultural background of Russia do not allow full use of waste in stable conditions of the Western economy methods of enterprise management. Improving the competitiveness of enterprises, a way out of this difficult economic environment requires the development and application of new approaches to management, more adequate to the current economic situation in Russia. Management in market conditions means, above all, the orientation of the enterprise on demand and market demand, constant desire to improve production efficiency, the search for new opportunities to obtain the best results at the lowest cost.

The economic condition of the enterprise as a whole is driven by three main factors: the level of engineering and technology; the quality of the workforce and the widespread use of labor motivation; management (management). The third of these factors has a strategic character. As shown by special studies, management status affects the level of engineering and technology, and the quality of the workforce. Modern management is a distinct sphere of economic relations that have their own logic of development. It is a separate type of professional activity aimed at achieving in the course of any business activity of enterprise in market conditions, certain of the targets through the rational use of material and labor resources with the application of the principles, functions and management practices.

\section{The Development of Management Science}

Management practice has been a rather long and deep evolution. In the early stages of capitalist production the 
entrepreneur-owner, as a rule, he ran the company, guided by experience and intuition. But the development of production at the turn of XIX-XX centuries in a new way raised the issue of governance. The development of technology and new technologies, increase production dramatically complicate the operation, has made it a special field of activities, requiring special knowledge. The need to solve problems has led to the generalization of the experience to the search for effective methods of production management and labor.

Arose the science of management. Technical progress, the development of production, socio-economic and political conditions put before the theory and practice of management of all new problems. Experts in the field of management at every stage of found solutions to these problems. The evolution of the theory and practice of management is reflected in the diverse manifestations. At first the plan was put forward one, then the other problems. In 50-60-ies in the spotlight was a management and organizational structure. In 60-70-ies occurs strategic planning. the 80s were marked by the transition leading foreign companies from strategic planning to strategic management.

In the course of evolution in the science of management has allocated different directions, it happened merge with other close to her science. The watershed year in the development of management was the consolidation of control theory and theory of marketing that gave rise to the concept of market management. The basic assumptions of the new concept are as follows:

- the emphasis is on man's self-fulfilling (unlike human economic human and social);

- $\quad$ the company is considered as a living organism, consisting of people, unite joint values as "the clan";

- the company should be in constant update, powered by internal desire and seek to adjust to external factors, the main of which is the consumer.

A new paradigm of management-based system, the situational approach. Enterprise open system. The main factors in its success depends not only inside but also outside of it. Success is associated with how well the firm fits into the external environment (economic, scientific, technical, socio-political) and adapts to it. That is the main criterion for the effectiveness of the management system consists of the following: whether the company time to recognize the threat to their activities, whether it is robust to changes in the market, do not miss the opportunities that arise in the external environment, will be able to derive maximum benefit from these opportunities.

\section{The Characteristic Features of the New Managerial Paradigm}

At the beginning of the transformation period the external environment had a fairly substantial effect on domestic enterprises, and they, in turn, were chosen as priorities in the management of internal variables strategy in organizational improvement. Currently the external environment has become more dynamic, rapidly changing. In this situation, the priorities should be given to the management system based on flexible decisions in conditions of uncertainty information.

However, the functioning of the enterprise in the marketplace is not simply a response to external stimuli, and a movable inner balance, which can be achieved only as a result of adaptation to uncertain external influences due to the exchange of information with the external environment. This requires the analysis of external factors as well as industry analysts have raised production efficiency while improving its elements based on the change in the influence of external factors.

The embodiment of the new approach is strategic management, which involves the addition of capacity planning enterprise planning his strategy on the basis of the future state of the environment. The change in the situation causes a change in the opportunities and change strategy. Special provision is made to reduce the resistance to change. The new operating concept requires new facilities to the staff, new management culture (the desire for radical change, risk tolerance, etc.). Experts rightly consider that there is no single, ideal model of governance, as every business is unique. It must find its own model. Among the factors that determine the choice of the management model are the following: size of the enterprise; product description; the nature of the environment in which it operates.

From the point of view of the nature of the environment in which the company operates, identify the following management model (Trenev, 2006):

- rational model of corporate governance in a peaceful external environment;

- management model in a fairly dynamic and diverse market;

- management model in terms of dynamic scientific and technological progress;

- model fit to spontaneously and unexpectedly arise under the influence of the external environment of the enterprise problems.

Enterprises are in continuous search for your model management. It is a continuous process, for changing the enterprise itself and its environment. Therefore, to ensure that management meets the needs of the enterprise, it needs to grow with the company and its external environment. For example, most American companies carry out separate 
organizational changes at least once a year, and a major restructuring exercise carried out every 4-5 years.

The General direction of evolution - the transition from the model of management in the conditions of mass production and relatively low level of competition to the model of governance in terms largely of individual production and heightened competition.

The modern system of management of enterprise development should be simple and flexible. Its main criterion is to ensure the efficiency and competitiveness of the enterprise.

Control theory considers the enterprise as a set of interconnected and properly arranged components that have the integrity and form a unity with the environment. The key point is a structure that is relatively stable relationships which exist between the elements of the company, design company, which is controlled by the company. This design includes the channels of authority and communication between the various units, as well as information that flows through these channels.

Ensuring the effectiveness of the management process is largely determined by the rational distribution of power in decision making between different levels of government, i.e. the ratio of centralization and decentralization in the management. The optimal balance of centralization and decentralization provides efficiency and realism of management decisions. Decisions must be made quickly and near the source of information you need to fully comprehend. Organizational management structure should ensure the maneuverability of production, the need for which may be attributed to the changing level of demand or competition: lower prices, the decrease in the share of firms in the market, the unexpected success of a new product.

Organizational principles of the enterprise are determined by its goals and strategy. Once identified goals, and develop guidelines for the actions and policies of the enterprise. The main objective of this policy is to clearly define strategic concepts by which decisions are made, appropriate short-and long-term goals of the enterprise. The objective of the enterprise depends on three main factors: the chosen strategy, organizational structure and how this structure operates. The task of the company is to achieve the goals for which it was created.

However, under the influence of rapid changes in the external environment, the nature of the goals and ways of achieving them can change. Therefore, the control system must be flexible. For this the company needs to have information about the internal state of Affairs and about competitors, clearly and quickly to solve various issues. Quick response to changing internal and external conditions is ensured by the transfer of the right of decision on the place of action.

Flexibility is required in matters of strategy. In cases of obsolescence, changes in technology, changes in social and legal restrictions, the company needs to quickly and accurately respond-to improve the range, change the market, etc. In this regard, at the forefront of this function of management as planning (current, strategic), whose goal is the elimination of the negative effect of uncertainty and variability of the environment of the enterprise, focus on core tasks, achieving cost-efficient operation and easy control.

The modern enterprise is a complex socio-economic and industrial system operating in a rapidly changing environment, which is a constant source of new opportunities and threats, creating a complex, heterogeneous and difficult to predict the situation. Namely, in such circumstances cease to work for an established, well-proven in the past the rules, methods and technologies, and there is a need for new approaches and theories.

In this regard, the effective management of enterprise development has been and remains a serious problem for the country's economic development. The global economic crisis, a sharp decline in industrial production has led many companies to crisis and bankruptcy, and to develop a comprehensive and effective methodology for the management of such enterprises still failed. In these circumstances, many businesses were unable to clearly define the main goals, priorities, formulate functional tasks. Generated and implemented marketing and competitive manufacturing strategy for many enterprises do not cover all of the issues they need to resolve.

Thus, the organization and management of effective enterprise development as a complex socio-economic system is one of the key problems of economic stabilization.

The modern enterprise management is today one of the most difficult tasks of managers of different branches. Traditional economy is retreating under the onslaught of the new, which imposes new requirements on businesses: changing relationships between enterprises, change the organizational structure of the enterprises themselves and standards management. The new economy requires new knowledge and new people, this knowledge is able to produce and use.

In the new economy expands and the composition of traditional factors of production (labor, land and capital) due to the inclusion of information and knowledge. Knowledge, creative work is beginning to play a significant role in the socio-economic development. The challenge facing Russian companies in these circumstances, to take into account the new realities of the knowledge economy and to develop appropriate principles for a new management paradigm to adopt 
modern domestic organization to succeed in global markets with new forms of competition and information technology.

Attribute management in social production is focused in the conduct and management of, and manufacturing processes. In this regard, it is important to develop the concept of management of the effective development of industrial enterprises, defined as making decisions on the use of resources and methodological tool that provides the most effective alternatives when making management decisions. It follows from this Central requirement for effective control - the adequacy of the used instrumentation control conditions in the socio-economic system in which social production functions. However, the factors and tools management decisions, being interconnected in the socio-economic system, developing according to the laws of evolution of its institutions, which leads to a certain level of mutual inadequacy, to overcome which need external purposeful action. To identify this inadequacy and to determine the nature of impacts to eliminate possible only within the boundaries of the managerial paradigm, this raises the problem of identifying managerial paradigm inherent in the specific socio-economic system of the functioning of social production.

A management paradigm is subjective, unique nature, which is determined by the socio-economic system. It changes due to the development of social production and its methods of control. The nature of managerial paradigm leads to the existence of significant non-formal and ideological factors in its structure. Informal factors can have both a historical nature, that is to be actually existing, but not yet to get scientific, ideological or any other generalizations and subjective nature actually apply the concepts and methods of management, but not declared to prevent formal identification conflict with officially declared the purposes and concepts of the government's strategy and goals of social production. The last case does not exclude a situation of de facto support of informal institutions management paradigm of official state and production management structures as reducing the degree of influence of the problems arising in the process of achieving formal and informal goals of the state, enterprises and individual managers.

On the basis of generalization of the results of theoretical research and practice can distinguish the characteristic features of the control system inherent to domestic enterprises and adequate to the new economy (table. 1).

Table 1. The characteristic features of existing and new management paradigm (compiled by authors)

\begin{tabular}{|c|c|c|}
\hline $\begin{array}{l}\text { The main characteristics of the } \\
\text { managerial paradigm }\end{array}$ & $\begin{array}{l}\text { The content of the existing management } \\
\text { paradigm }\end{array}$ & $\begin{array}{l}\text { The contents of the new management } \\
\text { paradigm }\end{array}$ \\
\hline The goal of the enterprise & $\begin{array}{l}\text { To maximize profits, increase market value } \\
\text { of shares }\end{array}$ & $\begin{array}{l}\text { Priority in the interests of customers, shareholders } \\
\text { and staff, meeting the requirements of a particular } \\
\text { consumer }\end{array}$ \\
\hline $\begin{array}{l}\text { The main management that } \\
\text { sustains the competitiveness of } \\
\text { enterprises }\end{array}$ & Senior management & Average and lower links management \\
\hline $\begin{array}{l}\text { The principle activities of the } \\
\text { organization }\end{array}$ & $\begin{array}{l}\text { Rational organization and functional } \\
\text { specialization, allowing you to respond } \\
\text { quickly to customer needs }\end{array}$ & $\begin{array}{l}\text { Basing on the knowledge and information that } \\
\text { allows you to respond quickly to the demands of } \\
\text { customers and employees }\end{array}$ \\
\hline Footage of the enterprise & Object management & $\begin{array}{l}\text { The subject of management, the media core } \\
\text { competencies of the company }\end{array}$ \\
\hline Motivation of managers & $\begin{array}{l}\text { The achievement of this goal, limited } \\
\text { achieved an average success }\end{array}$ & $\begin{array}{l}\text { The vision of the staff of the business objectives, } \\
\text { providing for its long-term survival in a changing } \\
\text { environment and competition }\end{array}$ \\
\hline Approach to competition & $\begin{array}{l}\text { A structural approach based on the } \\
\text { structural positioning of the enterprise in } \\
\text { relation to the external environment, } \\
\text { competitors }\end{array}$ & $\begin{array}{l}\text { Resource-based approach, based on identifying } \\
\text { and developing core competencies of the company }\end{array}$ \\
\hline Response to environmental change & Reactive & $\begin{array}{l}\text { Strategic, active use of the internal potential of the } \\
\text { enterprise in order to change the external } \\
\text { environment }\end{array}$ \\
\hline Style of management & Authoritarian, democratic elements & $\begin{array}{l}\text { Democratic conducive to the disclosure by } \\
\text { employees of their abilities, the formation of a } \\
\text { team of like-minded people }\end{array}$ \\
\hline Information & Strictly metered & Management by "open book" \\
\hline
\end{tabular}

The main objectives of the enterprise in modern conditions must become the interests of customers, shareholders and staff, meeting the requirements of a particular consumer. Knowledge and information should be sufficient to react flexibly to changing requirements of customers and employees. 
Average and lower links be the main management for competitive enterprise, because it is at these levels of management responsible for the operational decisions and orders, and the speed and accuracy of their adoption depends largely on the implementation of innovation in the enterprise.

The specificity of the innovation process as an object of management determines the specific character of the labor managers in this field and the demands placed on them. Since the main object of labor Manager is a scientific, technical and managerial information, dramatically increase its competence in the field of specialization of the company, communication and knowledge in the field of theory and skills in the area of management practice.

Footage of the enterprise become the subject of management, the carrier core competencies of the company. The vision of the staff of the business objectives, providing for its long-term survival in a changing environment and competition are motivational factor activity managers. The predominance of democratic leadership style contributes to the disclosure by employees of their abilities, the formation of a team of like-minded people.

\section{Conclusion}

Modern control system is based on the strategic reaction of businesses to the changing environment, the active use of the internal potential of the enterprise in order to change the external environment. Innovation must be part of the strategy of enterprise development, and not a response to competitors ' actions, which often leads businesses to bankruptcy.

Thus, the use of management tools adequate to modern conditions of social and economic system in which social production functions will ensure improvement of the process management of the enterprise to achieve its effective development.

\section{References}

Altukhov, S.I. \& Mitsuk I. 2006. Innovation management: Monograph. Novosibirsk: MAN.

Afanasev, N.In. \& Rogozhin V.D. 2003. The management of enterprise development: Monograph. Kharkov: Publishing house "INJEC". Trenev, N.N. 2006. Methodology strategic management of an enterprise on the basis of self-organization. Consultant Director, 21. pp. $10-25$.

Aspridis, G., Kazantzi V. \& Kyriakou D. 2013. Social Networking Websites and Their Effect in Contemporary Human Resource Management - A Research Approach. Mediterranean Journal of Social Sciences. MJSS Vol 4 No 1 January 2013. pp. 29-46.

Dimitrios, Kanellopoulos 2012. Human Resource Management in the Europian Health System-A Comparative Approach. Mediterranean Journal of Social Sciences. MJSS Vol. 3, No. 1, January 2012. pp. 339-350. 